\title{
Constantin Ripa - analytical aspects of choral creation
}

\section{Maria Marina SIMIONESCU*}

Abstract: One of the most prolific authors of the Romanian choral music, the composer and conductor Constantin Ripa is a personality of insufficient importance in the Romanian musical writings. His choral scores really meet the attributes and meanings in which metatonality is manifested. The richness of the means of expression and the use of specific sound systems bring diversity through the multitude of themes approached by the composer. In the ensemble of choir creation of the composer we will meet: choirs for equal voices, children choirs, mixed choirs, including: songs - children's games, adaptations and potpourries of Romanian folklore, own creations of folklore and religious inspiration, choruses on Ovidiu, Mihai Eminescu, Ion Barbu, Lucian Blaga, Vasile Voiculescu, Otilia Cazimir, Mircea Stefanescu. The different periods of creation are distinguished from the perspective of the elements of language, which represent a constant in the personal style as a whole, but also reflect the composer's choices in accordance with the spirit of the times, but also with the repertory necessities of the choral ensembles, especially the Antiphony choir that he led with 1969. From the first stage of creation, the Cântece de anotimp on poet Lucian Blaga's poetry reflects a modal-chromatic thinking with a intonational substrate and an ethos taken from the Romanian folk music. At the

* PhD, Lecturer, Faculty of Orthodox Theology at "1 Decembrie 1918" University, Alba Iulia, Romania. 
end of the 1970s, in the works of Codex Caioni, Protomusica, Pax ades, Transilvania, Teapa lui Dracula, we can see the composer's preference for the themes of history and the ancestral past. The choral creation of the composer Constantin Ripa gives musicologists the panorama of a live repertoire, rich in artistic significance and expressiveness.

Keywords: Romanian composer, Romanian choral music, metatonality, conductor, Antifonia choir, contemporary music, choral creation, tonal systems, Romanian ethos.

Extensive personality for the Romanian choral music world The composer and conductor Constantin Ripa is one of the most prolific authors of choral music, insufficiently marked in Romanian musical writings.

His choral scores truly meet the attributes and meanings in which the all-embracing system of metatonality is manifested. The abundance of the choral genres approached, the multitude of thematic themes, attract the riches of means of expression and implicitly the use of sound systems specific to the material chosen for the processing or the spirit, the ethos created in them. Thus we will meet in the ensemble's choir's creation: choirs for equal voices, children's choirs, mixed choirs, including: songs - children's games, adaptations and dances of Romanian folklore, own creations of folklore and religious inspiration, verses choirs by: Ovidiu, Mihai Eminescu, Ion Barbu, Lucian Blaga, Vasile Voiculescu, Otilia Cazimir, Mircea Stefanescu, and others.

His creative periods will be analyzed from the perspective of elements of language, elements that present a constancy in the personal style as a whole, but reflect the composer's preoccupations and choices in accordance with the spirit of the times, but also with the repertory needs of the choral ensembles, led him from 1969. As the conductor of this prestigious choral 
band specializing in contemporary music, the composer made first auditions of masterpieces of Romanian and universal choral music, thus contributing to the enrichment of the cultural and spiritual "heritage" of musical contemporaneity.

The 70s marks a creation that reflects the composer's choice to a style close to the core of the avant-garde music, with influences of random music, vocal and extracoceal effects, a chromatic modalism with rubato-doinit, or abstract-atonal, heterologous textures, free polyphonic, a harmonic system that includes the cluster, the quartet quartet mixes, the melodic or harmonic non-octave frame, the polyfunctionality, other nonmodal elements of the musical material approach.

From this first stage of creation, the choral cycle Songs of Seasons (Cantece de anotimp), Lucian Blaga's poetry reflects a modal-chromatic thinking in which melodic ideas are displayed, having a intonational substratum and an ethos taken from the Romanian folk music.

In the first choir, Spring Fire (Focuri de primavara), starting from a tricordial, and-do-do \# chromatic structure, the composer creates a texture made up of attack polyphons that completes a 9tone chromatic scale:

Ex. Spring fires (Focuri de primavara) ${ }^{1}$ - polyphony attacks of attacks on do and do \#.

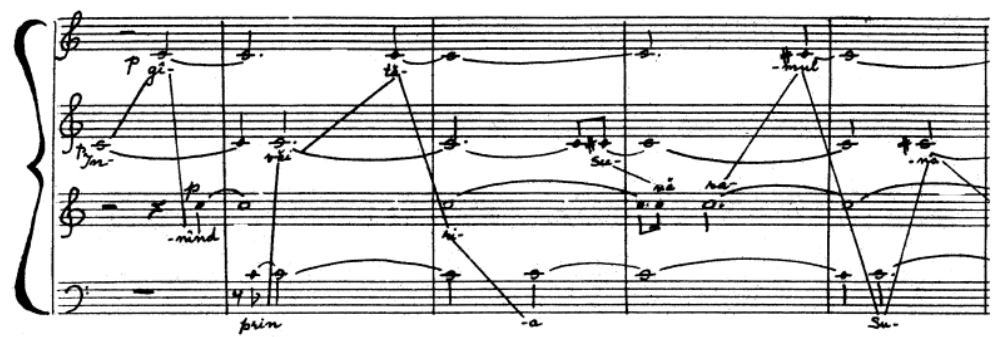

1 Constantin RîPĂ, Songs of Seasons, Music Conservatory "Gheorghe Dima”, 1971. 
Spatialisation of a hexatonatal structure on 8 symmetrical movement voices, symbolizing the opening of the corolla, the blooming is spectacularly made in the end:

Ex. Spring fires (Focuri de primavara):

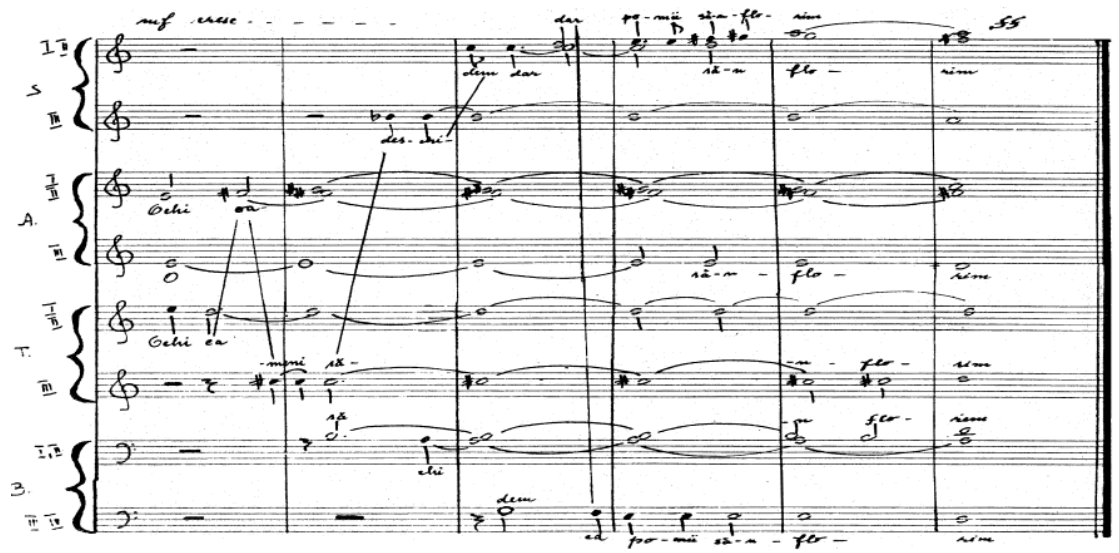

In the Heart of the Woods Choir (Inima padurii), the composer realizes, through the means of the recitative and intonational structures of quintet, the resonance with the archetypal structure of the poetic metaphor, simply constructing, a speech of a disturbing placement in ancestrality, in a spell in a chant.

Ex. Heart of the forest (Inima padurii) ${ }^{2}$ :

2 Constantin RîPă, Songs of Seasons, Music Conservatory "Gheorghe Dima", 1971. 

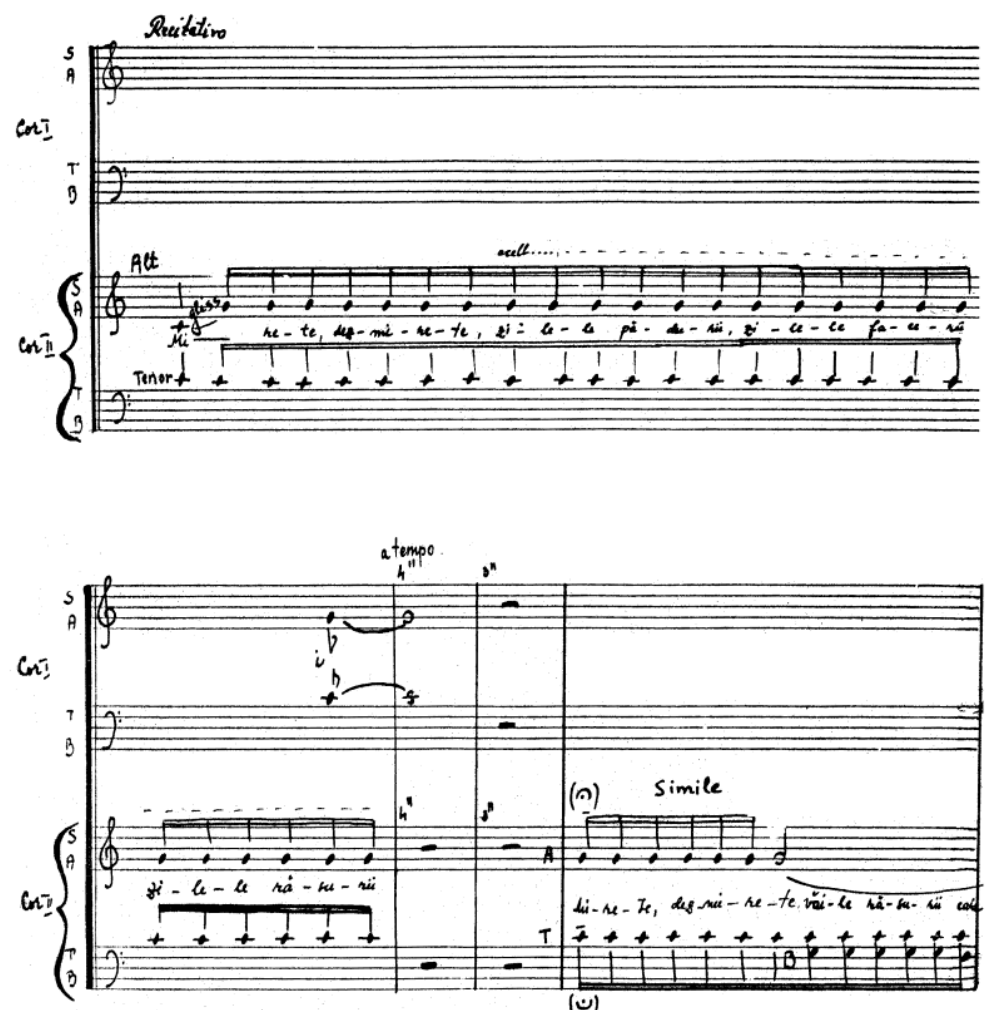

In the Song of spikes Choir (Cantecul spicelor), the composer explores the chromatic sounds in the sense of the slope chrome, realizing a melodic dynamics that is fulfilled in bifunctional arrangements:

Ex. Song of spikes (Cântecul spicelor):

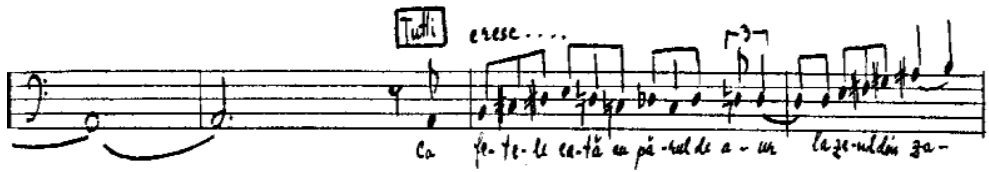




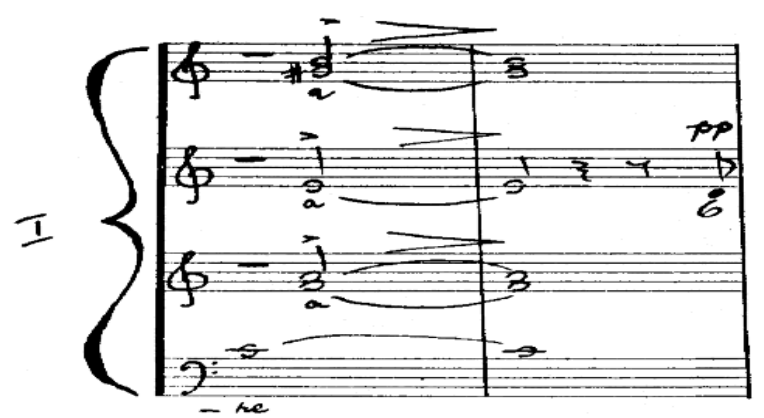

The same recitative, this time, cowboy, is placed in the bones of the choir. The song of the traveler in the autumn (Cantecul calatorului in toamna), over which the other parties construct a texture made up of quartet structures in vibrant glissando and symmetrically symmetrical movements that suggest the sound of the wind.

At the end of the 70's and the 80's of the 20th century, the composer sought to enrich the choral repertoire of popular songwriting to make the inexhaustible intonation beauties worthwhile: Pliny is a loud voice( Plinu-I codrul de voinici), Cicoarea ballad( balada Cicoarea), satirical song ( Cantec satiric), Run (Galop) , Song of Fun (Cantec de haz), Lioara, Wedding Ceremony (Ceremonial de nunta), Shouting Game (Strigare de joc), Winter Song ( Canec de iarna), etc. In parallel, the workings of the Codex Caioni, Protomusica, Pax ades, Transilvania, Dracula's Feet (Teapa lui Dracula), reflect the composer's preference for historical themes and the ancestral past.

In the choral processing, the composer uses an arsenal of means of expression that conforms to the modal specificity of the manifested source and the inspirational themes. Thus, the imitative polyphonic processing in the stretch, the harmonization with the pedals of the ison type, or with the pedals in the case of the expressiveness of the instrumental folk or dance instrumental music, the use of plagical clashes in the conditions of a trisonic 
tunnel, sometimes tonal-functional, sometimes modal, remaining constant various extravascular effects (palm beatings, whistles, whistles, imitation of onomatopoeic effects, etc.).

In the song of Voievodesei Lupu in the Codex Caioni cycle, the composer exploits the real charm of the old melody, revolting by modal harmonizing with trisons in the spirit of renaissance music, finding different color variations at each repetition, in the manner of harmonic variations. The beautiful frigid cadence is also colored with a harmonic conclusion to the subton in the spirit of popular song.

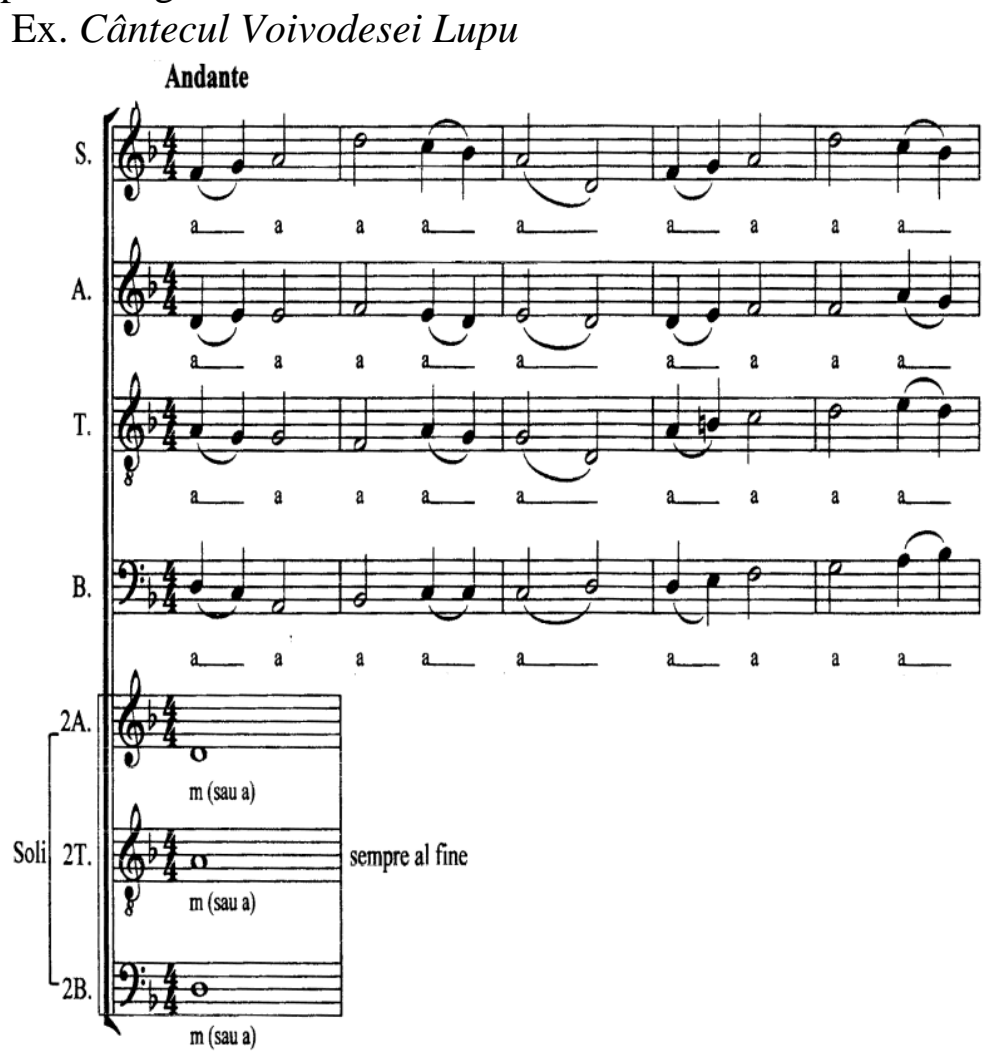


Ex. Cantecul Voivodesei Lupu

A.

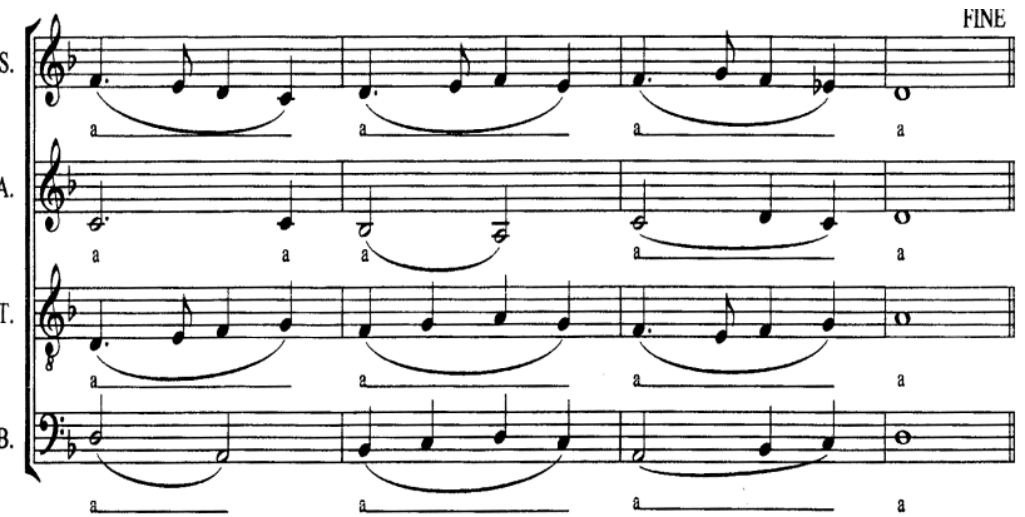

In the Pax choir, on the lyrics of the ancient poet Ovidiu, the composer exploits the same diatonic modal source, with chromatic irises, in a melodic-harmonic inspired discourse, in which he uses melodic outlines reminiscent of ornamental and intonational ethos of the Greek-Byzantine figure.

The modal coral from the beginning of the work is built on the principle of symmetry, graphically setting an opening of the voices towards cadence. The modal frame to the eolic will be metamorphosed throughout the work due to the inherent polyphonic processing.

Ex. Pax ades:

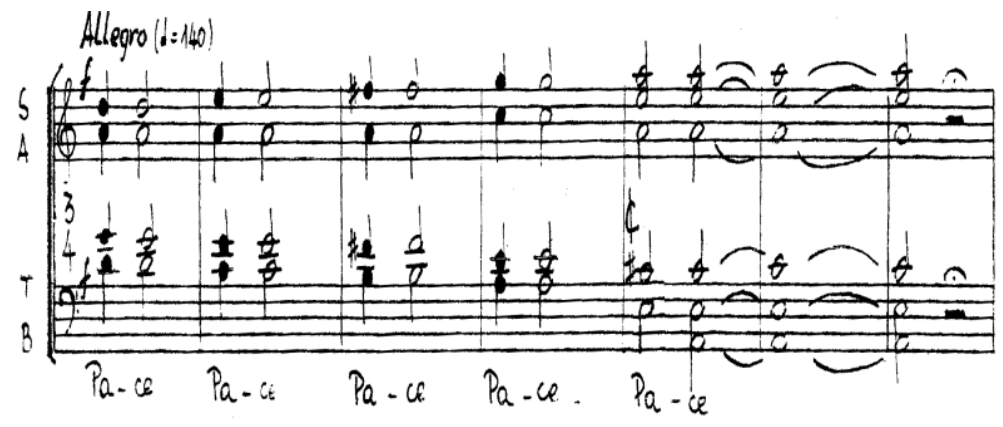


The harmonic recitative and the imitative polyphony are the basis of the buildup, whose modal material is constantly metamorphosed in melodic kneading. We observe how at the second repetition of the lyrics Tu ducibus, the melodic profile is made up of two hexachords conjunctions: the lidian hexacord and the frictional hexacord.

Ex. Pax ades:

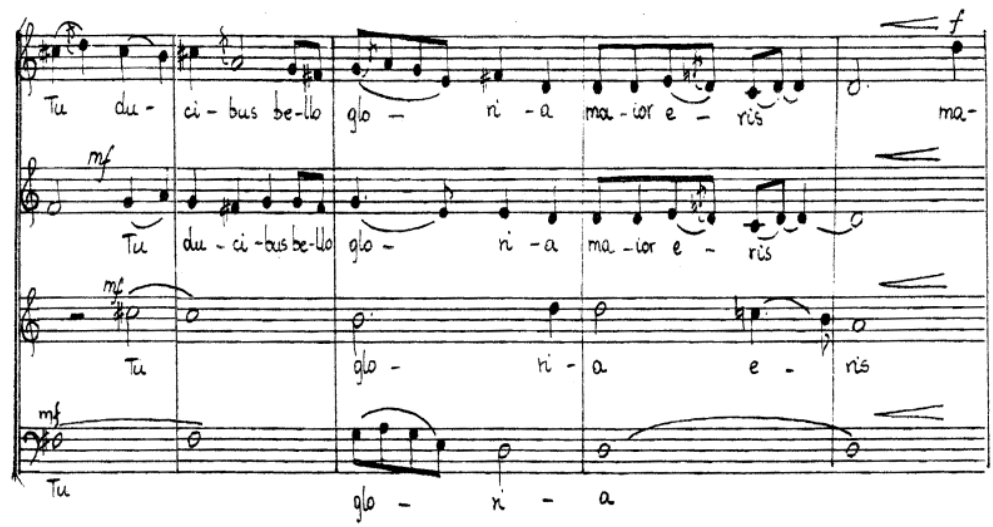

The scales:
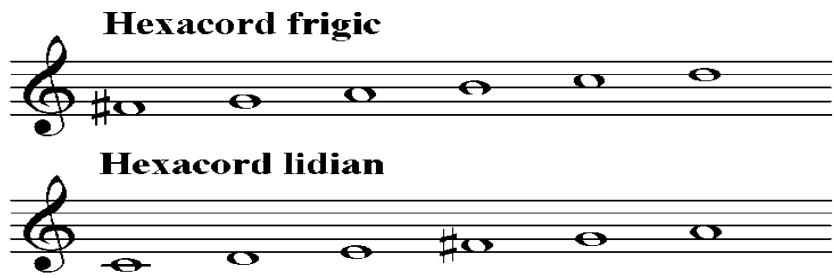

In the middle part, based on an ostinato of alto vocals and the alternative solist of the soprano, tenor, bass, the modal center moves from an eolic pentacord on me, on an ionic pentacord to the bass soloist. The crooked sound of the accompaniment, in which the choral voices enter successively, consists of sounds that form a chromatic scale.

Ex. Pax ades: 
Maria Marina

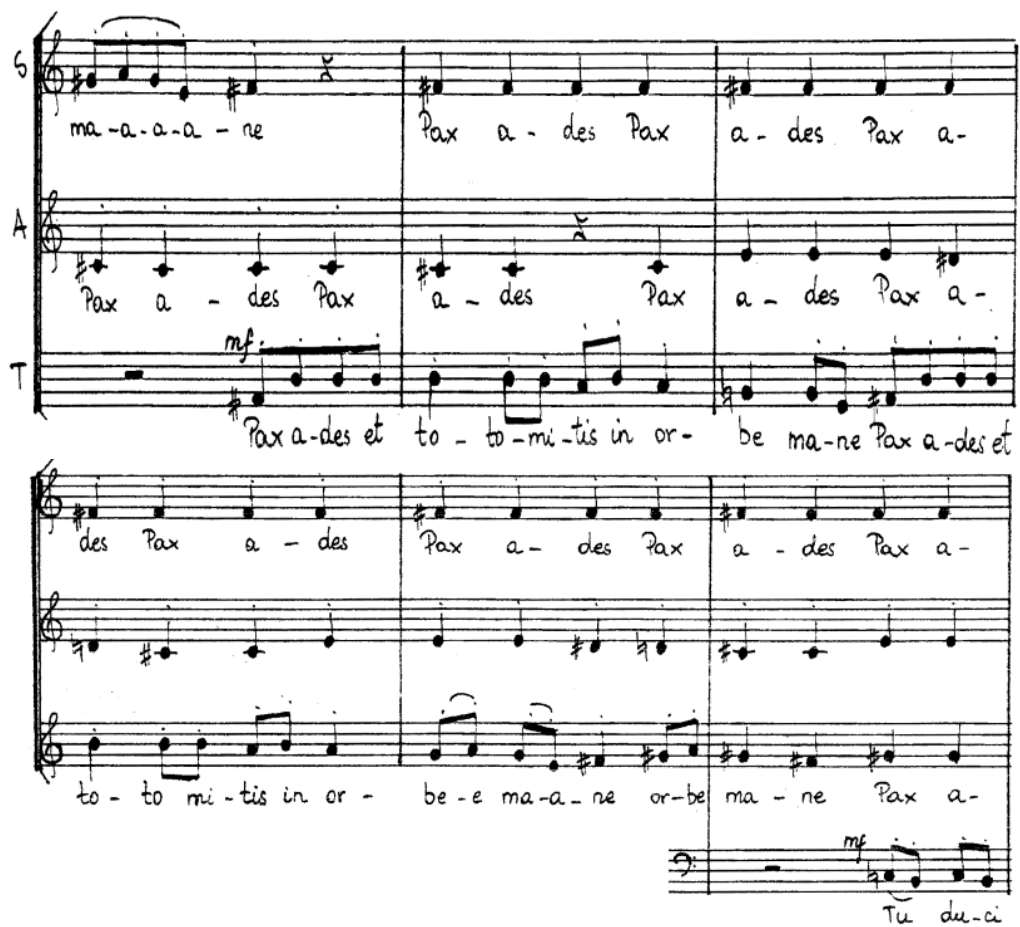

The presence of the lidian cluster, the quartet agreements, confirms the wealth of modal means by which the composer makes sense of this original work.

Ex. Pax ades:

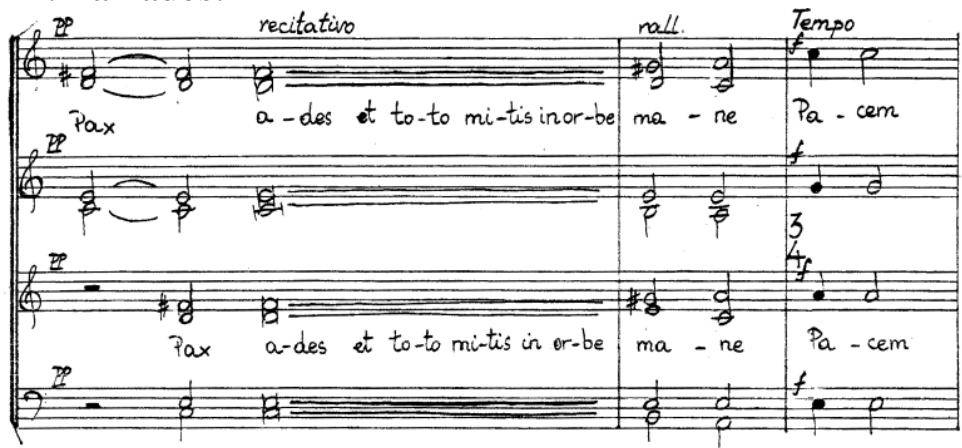


Constantly, the chromatic modality will be at the basis of some creations that demonstrate the composer's quests in the realm of exploitation of the folkloric way, whose expressiveness corresponds to the resonances of the Romanian spirituality of Mihai Eminescu's poems in Codrule codruţule, or Lucian Blaga, I do not strike the wondrous corollary of the world. The pleasure of exploring the valences of crowded or rarefied texture, based on heterologous overlaps of structures of various harmonic-melodic colors, in working with the musical metatonal framework represents a stage of expressive quests by Constantin Ripa.

Using chanting, whispering, rhythmic speech, the composer induces the atmosphere shrouded in the mystery of the sound of the words of the Blagian poem. The overlapping of various harmonic structures, the third quartet mixes, creates a harmonic framework specific to the agglomerated texture, in which the melodic outline exploits the pentadord solved in the melodic movement of the chromatic formula that has been turned.

Ex. I'm not crushing (Eu nu strivesc) $)^{3}$ :

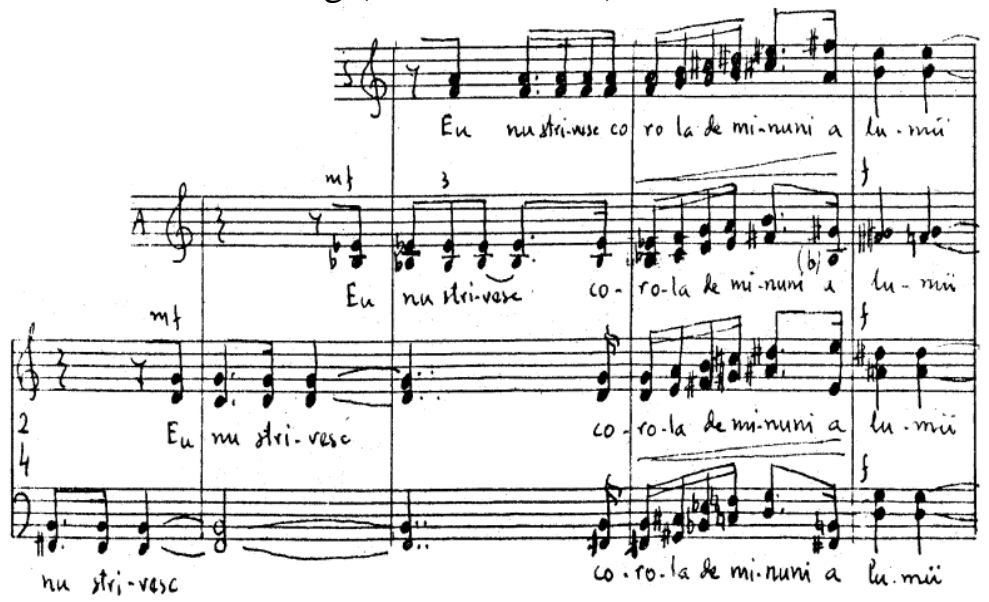

${ }^{3}$ Constantin RîPĂ, The wreath of wonders, by the poet's Lucian Blaga, Music Coservatory „Gheorghe Dima”, 1988. 
Maria Marina

SIMIONESCU

The free textures reflecting the "shredded" melodic of the solitaire recitative reminds of the doinit song formulations, intensely chromated, which glissandi receives mournful expressiveness.

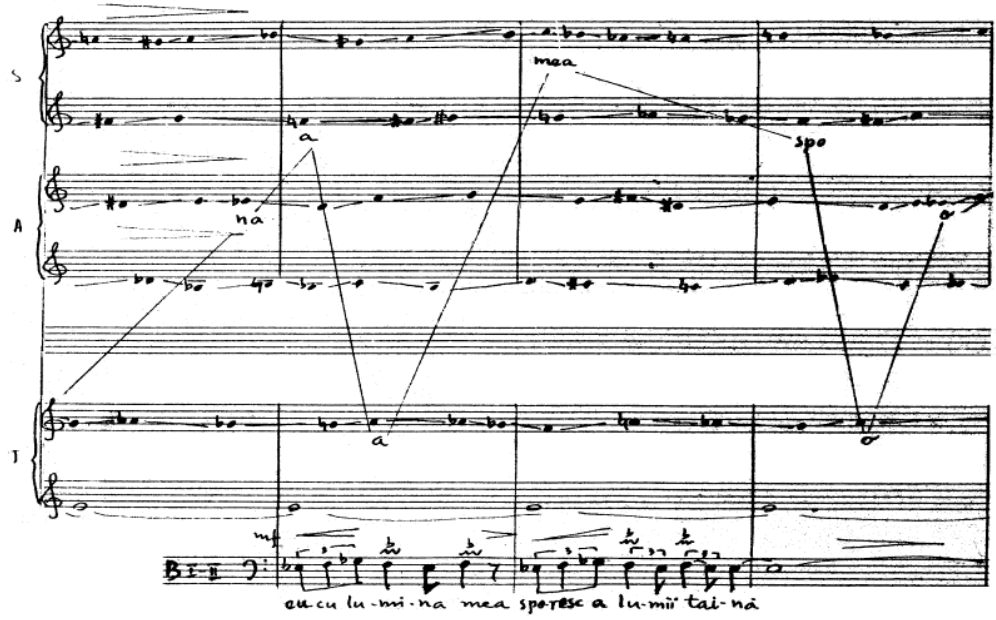

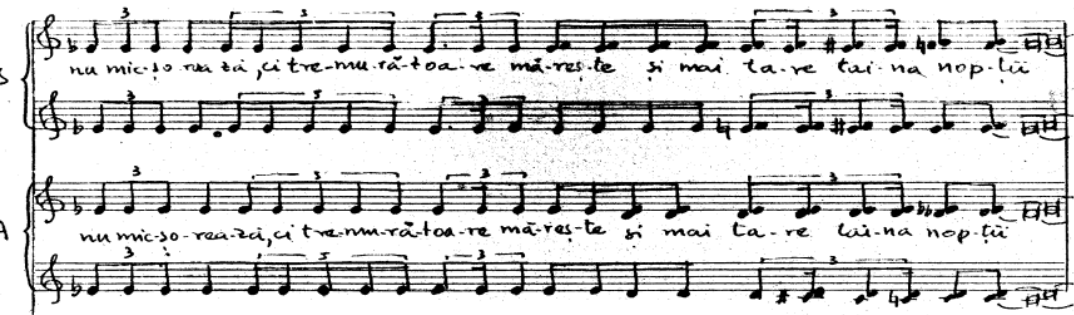

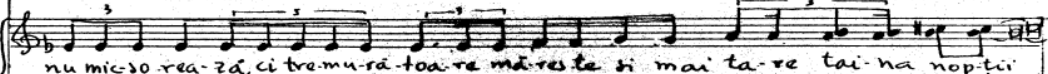
(j)

年:

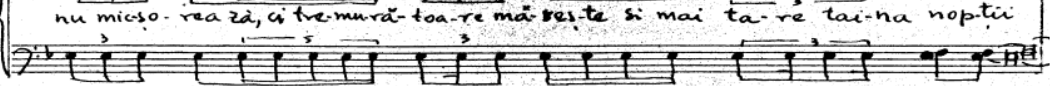


In the Codrule choir (Codrule codrutule), the herophonic texture reaches the maximum point of agglomeration through the existence of three ideas, modal segments with folkloric specific drawings that overlap, creating a continuously changing mosaic, a kaleidoscopic image and integrating specific Romanian intonations.

We observe the contours of a localized pentacord with an enlarged second to the sopranos of a mixolidic tetradord on a re that turns into a hetonic alto tetraton over which the bass solist consists of a hemitonic pentatony.

Ex. Codrule codrutule":

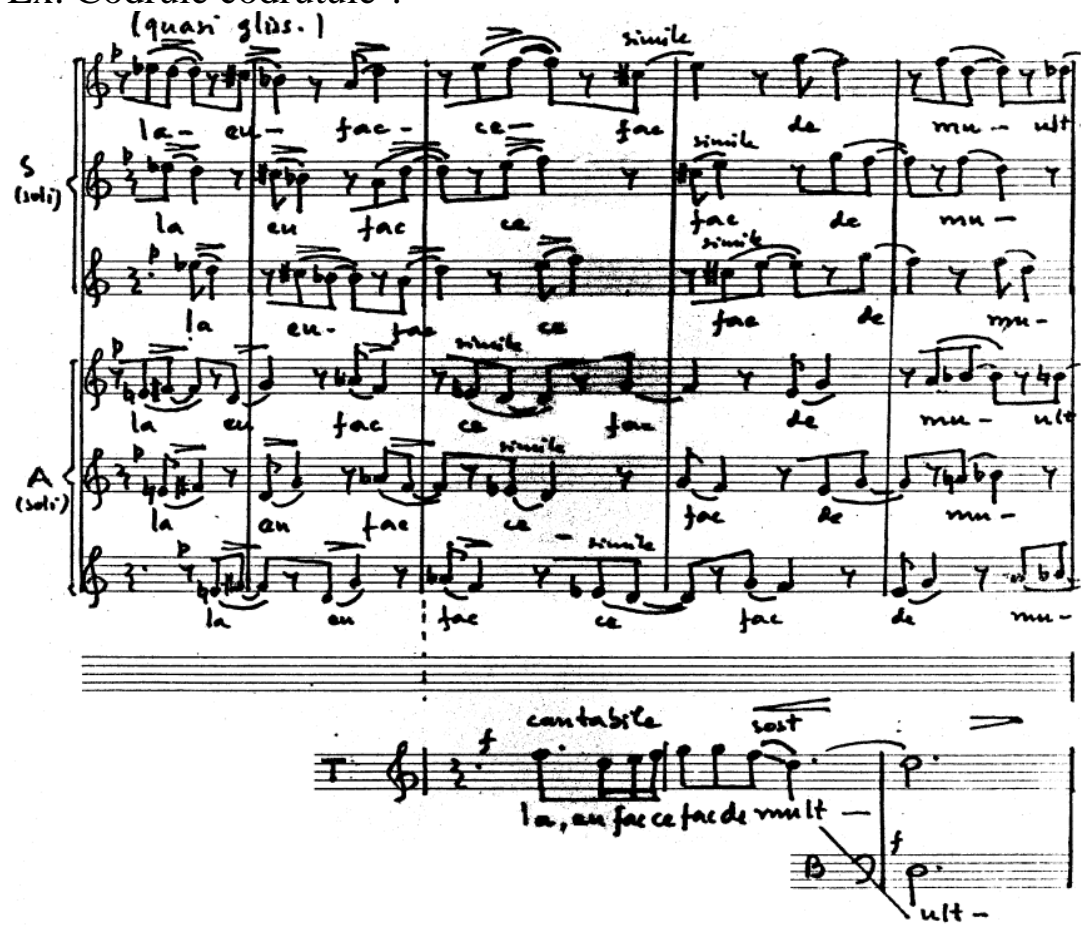

${ }^{4}$ Constantin RîPĂ, Codrule, codruţule, for mixed chorus, on lyrics by Mihai Eminescu, Music Conservatory „Gheorghe Dima”, 1989. 
All of these specific modal modalities construct "heterogeneous diagonal" textures in which the total chromatic field manifests itself in all registers. The overlapping of intonational elements in the manner of the doinit song organized, with rhythmic, random moments, potentiating the valences of the Romanian ethos, culminates in a unison in which the choir echoes upward two modal ladders: at the Doric and Doric sire ascending, and descending a progressively enlarged scale: 1 -1-3-1-4-1-5.

Ex. Codrule codrutule:

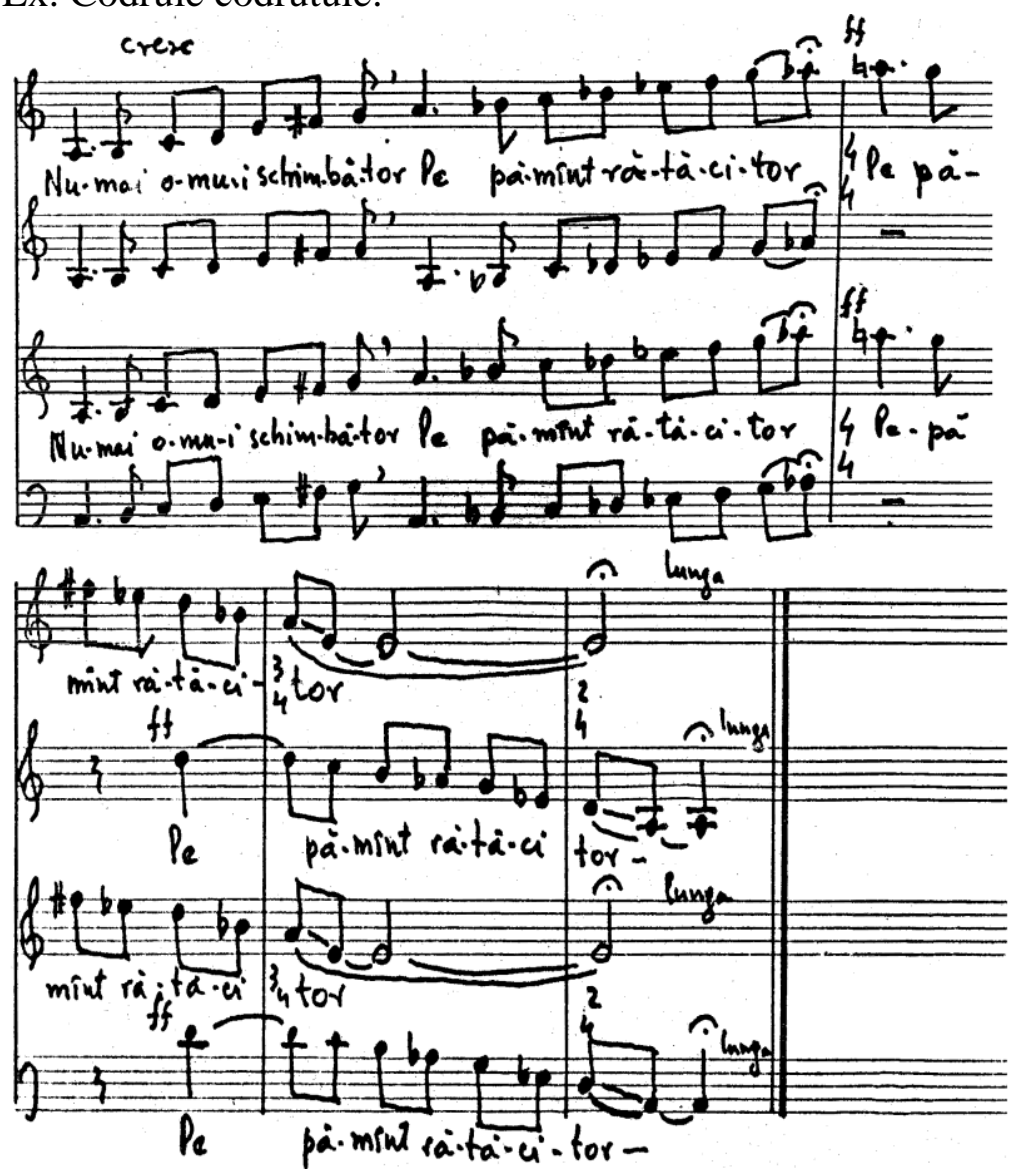


The choral creation of the composer C. Ripa gives the musicologists the panorama of a repertoire, alive, rich in significance and artistic expressiveness.

\section{References}

1. ANGHEL, Irinel, Directions, currents of Romanian music from the second half of the 20th century, Musical Publishing House, Bucharest, 1997.

2. CARANICA-FUlEA, Mihaela, „Creations of composers from Cluj”, in Muzica magazine, no. 8 of 1976, p. 6-10.

3. Cosma, Viorel, Musicians from Romania, Vol. VIII, P-S Music Publishing House, Bucharest, 2005.

4. FIRCA, Gheorghe, Modal Basics of Diatonic Chromatics, Musical Publishing House, Bucharest, 1966.

5. HERMAn, Vasile, Form and Style in the New Romanian Music Creation, Music Publishing House, Bucharest, 1977.

6. HeRMAn, Vasile, Cornel Ţăranu, Medaillon, , in rev. Music no. 2 of 1981.

7. HeRman, Vasile, Form and Style in the Creation of S. Toduţă's Composer, in Todu's Studies, MediaMusica Publishing House 2003.

8. POPOVICI, Doru, Romanian Choir Music, Music Publishing House, Bucharest, 1966.

9. RîPĂ, Constantin, Superior Music Theory, Vol I, Tonal Systems, MediaMusica Publishing House, Cluj-Napoca, 2001.

10. RîPĂ, Constantin, The Superior Theory of Music, vol. II, The Rhythm, MediaMusica Publishing House, Cluj-Napoca, 2002.

11. SANDU-DedIU, Valentina, Romanian Music between 19442000, Musical Publishing House, 2002.

12. TERENYI, Ede, Harmony of Modern Music, 1900-1950, Gh.Dima Music Conservatory, Cluj Napoca, 1983. 